\title{
Relationship between Nutrition Intake and Hemoglobin Levels in Toddlers Aged 12-24 Months
}

\author{
Triastika Ayu Nurjannah, ${ }^{1}$ Fardila Elba, ${ }^{2}$ Sefita Aryuti Nirmala, ${ }^{2}$ Ariyati Mandiri, ${ }^{2}$ \\ Merry Wijaya ${ }^{2}$ \\ ${ }^{1}$ Midwifery Study Program Faculty of Medicine Universitas Padjadjaran, Indonesia, \\ ${ }^{2}$ Department of Public Health Faculty of Medicine Universitas Padjadjaran, Indonesia
}

\section{Abstract}

Background: The toddler period is a crucial life period and needs special attention. Toddlers need to have a proper amount and good quality of nutrition from daily food to prevent anemia. This study aimed to explore the relationship between nutritional intake and $\mathrm{Hb}$ level in toddlers aged 12-24 months in Sumedang District, West Java, Indonesia.

Methods: This was a cross-sectional quantitative conducted in August-November 2019 on 96 toddlers aged 12-24 months. Toddlers were recruited using proportioned simple random sampling method. The mothers of these toddlers were asked to complete a food record for three consecutive days for their toddlers. Data were then processed using the Nutrisurvey application while the hemoglobin (Hb) level was measured using a Digital $\mathrm{Hb}$ tool. All data were analyzed using a Pearson Correlation Test.

Results: Most mothers of these toddlers graduated from senior high school (45.8\%) and were housewives (78.1\%). The iron requirement was met 61 toddlers (63.5\%). Most toddlers were not anemic (56.3\%) with a mean $\mathrm{Hb}$ of $10.99 \mathrm{gr} / \mathrm{dl}$. A relationship was established between iron intake and $\mathrm{Hb}$ level $(\mathrm{p}=0.000)$.

Conclusions: Low iron intake is associated with $\mathrm{Hb}$ level in toddlers aged 12-24 months in Sumedang District, West Java Province, Indonesia. A nutrition program needs to be well set-up for toddlers in this area.

Keywords: Hemoglobin levels, nutritional intake, toddlers

\section{Introduction}

Toddlers need to have a proper amount and right quality nutrients from daily diets; therefore, the toddler period is a crucial life period and needs special attention. Toddlers under five are among those who are vulnerable to malnutrition. According to the Nutrition Adequacy Ratio (NAR), proper nutritional intake is needed for toddlers under five to prevent anemia, ${ }^{1}$ in which hemoglobin (Hb) levels are lower than normal values. ${ }^{2}$ hemoglobin $(\mathrm{Hb})$ is an oxygen-carrying compound in red blood cells, ${ }^{3}$ and the level $\mathrm{Hb}$ is a parameter used to determine the prevalence of anemia.

According to the 2018 Basic Health
Research (Riset Kesehatan Dasar, RISKESDAS), the prevalence of anemia in toddlers under five is $38.5 \% .{ }^{4}$ Anemia is more common in toddlers aged 12-17 months than in toddlers aged 36-49 months The influencing factor is among others the increased physiological needs, whereas the need for iron will also increase at the age of one year. In this period, anemia iron deficiency increases, besides there is insufficient absorption of iron and bleeding. ${ }^{5}$ The occurrence of anemia in toddlers is generally caused by low levels of hemoglobin in the blood due to a lack of nutritional intake. If the nutritional intake does not meet the amount and composition of balanced nutrients, it may cause anemia. ${ }^{6}$

Anemia due to a lack of nutrients plays a role

Correspondence: Triastika Ayu Nurjannaha, Midwifery Study Program Faculty of Medicine, Universitas Padjajaran, Jalan Raya Bandung Sumedang KM 21, Jatinangor, Sumedang Indonesia, E-mail: triastikaayu@gmail.com 
in hemoglobin formation, for example, due to lack of consumption or absorption disorders. The nutritional substances referred to includes iron, which functions as a catalyst to form hemoglobin. ${ }^{7}$ Iron is an essential microelement for the body, needed for blood formation to synthesize hemoglobin. Excess iron is stored as protein ferritin and hemosiderin in the liver, spinal cord, and the rest in the lymph and muscles. The main difficulty in meeting iron needs is the low absorption rate of iron in the body, especially iron from plant sources, which only being absorbed for $1-2 \%$. Low iron intake is common in individuals who eat a less diverse diet. Also, lack of food supply, poor food distribution, poverty, and ignorance, coupled with the habit of consuming foods that can interfere with the absorption of iron such as coffee and tea at mealtimes, resulting in lower iron uptake. Lack of iron intake, low iron reserves in the body, or a lot of blood loss, will cause anemia to appear rapidly. ${ }^{8}$

The efforts that can be done to overcome the problem of anemia in toddlers are by consuming foods rich in iron (Fe). This study aimed to determine the relationship between nutritional intake and $\mathrm{Hb}$ levels in toddlers aged 12-24 months.

\section{Methods}

This was a quantitative study with a crosssectional design conducted at the South Sumedang Public Health Center, Sumedang Regency, West Java, in August-November
2019, after obtaining approval from three authorized agencies, including the Sumedang Health Department, Sumedang Community Public Health Center, and the Health Research Ethics Committee Universitas Padjadjaran no. 1009/UN6.KEP/EC/2019. The sampling technique was probability sampling with the proportioned simple random sampling method.

The study instruments were a food record questionnaire and a Digital $\mathrm{Hb}$ tool (Easy Touch GCHb). The mothers of the toddler were asked to record the food intake within three days. The data were further processed using the Nutrisurvey application and analyzed using a Pearson Correlation Test.

\section{Results}

In total, this study included 98 toddlers aged 12-24 months. The education of the mothers was mostly senior high school (45.8\%), and the most mothers were housewives $(78.1 \%)$ (Table 1).

Of 96 toddlers, $43.8 \%$ had anemia. The mean hemoglobin level of a toddler underfive aged 12-24 months was $10.99 \mathrm{gr} / \mathrm{dl}$ $+/-1.6$ (range 7-15). Based on nutritional intake, it was found that iron intake was not fulfilled in 35 (36.5\%) respondents (Table 2). The average of iron was $14.93 \mathrm{mg}+/-11.9$ (range 1-63), indicating that the adequate level of iron intake for toddlers the standard of nutritional adequacy. The normal value of iron intake for toddlers aged 12-24 months was

Table 1 Characteristic of the Mothers who have Toddlers Aged 12-24 Months

\begin{tabular}{lcc}
\hline \multicolumn{1}{c}{ Characteristics } & n & \% \\
\hline Education & & \\
Elementary School & 13 & 13.5 \\
Junior High School & 25 & 26.0 \\
Senior HighSchool & 44 & 45.8 \\
College & 14 & 14.6 \\
Occupation & & \\
Housewife & 75 & 78.1 \\
Labor & 2 & 2.1 \\
Entrepreneur & 13 & 13.5 \\
Civil servant & 1 & 1.0 \\
Teacher & 2 & 2.1 \\
Lecturer & 1 & 1.0 \\
Midwife & 1 & 1.0 \\
Doctor & 1 & 1.0 \\
\hline
\end{tabular}


Table 2 Distribution of Hemoglobin Levels and Nutrient Intake among Toddlers Aged 12-24 Months from South Sumedang Public Health Center, Sumedang Regency, West Java

\begin{tabular}{lcc}
\hline \multicolumn{1}{c}{ Variable } & n & \% \\
\hline Hemoglobin levels & & \\
$\quad$ Anemia & 42 & 43.8 \\
$\quad$ No anemia & 54 & 56.3 \\
Iron intake & & \\
Fulfilled & 61 & 63.5 \\
$\quad$ Not fulfilled & 35 & 36.5 \\
\hline
\end{tabular}

Table 3 Value of Hemoglobin Levels and Nutritional Intake

\begin{tabular}{lccccc}
\hline \multicolumn{1}{c}{ Variable } & Mean & Median & $\begin{array}{c}\text { Standard } \\
\text { Deviation }\end{array}$ & Min & Max \\
\hline Hemoglobin levels & 10.99 & 11.00 & 1.688 & 7 & 15 \\
Iron & 14.93 & 12.10 & 11.965 & 1 & 63 \\
\hline
\end{tabular}

$8 \mathrm{mg} /$ day. There was a correlation between iron intake and $\mathrm{Hb}$ level $(\mathrm{p}=0.000)$ as shown in Table 3. There was a relationship between iron protein intake and $\mathrm{Hb}$ levels $(\mathrm{p}=0.000)$ (data not shown).

\section{Discussion}

This study has shown that there is a relationship between nutritional intake and hemoglobin levels $(\mathrm{p}=0.000)$, as 42 toddlers $(43.7 \%)$ have anemia, suggesting nutritional deficiencies since there is an unfulfilled iron intake in (36.5\%). This is in line with research by Nurhidayati ${ }^{9}$, which states that there is a significant relationship between nutritional intake and hemoglobin level. Lack of nutritional intake or food intake will result in malnutrition, affecting the speed of hemoglobin formation, and the blood concentration decreases, causing hemoglobin levels to fall. This occurs because there is insufficient iron available for the formation of hemoglobin, so that the production of hemoglobin is lower than normal, thus, it is possible to develop anemia. ${ }^{10}$

Anemia is a condition in which the number of red blood cells is reduced or does not contain enough hemoglobin. Hemoglobin is found in red blood cells, which carry oxygen to body tissues and develop body tissues. Anemia in toddlers under five causes growth disorders and various disease susceptibilities. The toddlers may look pale, lethargic, and have reduced appetite. The process of forming hemoglobin in the body requires nutritional

Table 4 Relationship between Nutritional Intake and Hemoglobin Levels of Toddlers Aged 12-24 Months

\begin{tabular}{lcccccccc}
\hline \multirow{2}{*}{ Iron intake } & \multicolumn{7}{c}{ Hemoglobin levels } & \multirow{2}{*}{ Score P* } \\
\cline { 2 - 7 } & \multicolumn{2}{c}{ Anemia } & \multicolumn{2}{c}{ No Anemia } & \multicolumn{2}{c}{ Total } & \\
\cline { 2 - 7 } & $\mathbf{n}$ & $\mathbf{0}$ & $\mathbf{n}$ & $\mathbf{\%}$ & $\mathbf{n}$ & $\mathbf{\%}$ & \\
\hline Fulfilled & 16 & 26.2 & 45 & 73.8 & 61 & 100 & 0.000 \\
Not fulfilled & 26 & 74.3 & 9 & 25.7 & 35 & 100 & \\
\hline
\end{tabular}

Note: *Pearson Correlation Test 
intake. Therefore, to prevent anemia, toddlers under five should consume, among others, liver, meat, fish, eggs, avocado, nuts, spinach, and seeds. Hemoglobin is the main protein in the human body that functions to transport oxygen from the lungs to the peripheral tissues and vice versa to transport $\mathrm{CO}^{2}$ from the peripheral tissues to the lungs. ${ }^{11}$

Furthermore, the average iron intake in toddlers aged 12-24 months in this study was $14.93 \mathrm{mgm}$ which has met the nutritional adequacy standard. The Nutritional Adequacy Rate (NAR) for toddlers aged 12-24 months is $8 \mathrm{mg} /$ day. Maternal education, mother's occupation, family income, number of toddler, and mother's parenting style may play important role in nutritional adequacy. ${ }^{12}$ This is confirmed that the mothers have a high school education (45.8\%) and work as housewives (78.1\%). There is a significant relationship between maternal education and maternal knowledge about anemia. ${ }^{13}$ This impacts the nutritional intake of toddlers under-five which will affect hemoglobin levels with a significant value. It is known that the higher the maternal education, the better knowledge in preventing anemia because the higher a person's education level, the easier it is to receive information so that the more knowledge one has. The level of maternal knowledge about nutrition as a housewife will affect the type of food consumed daily. There is a significant relationship between maternal occupational status and maternal knowledge about anemia $(p=0.003)$. Mother's status and type of work may affect the availability of time to manage food because they tend to determine the diversity of household food consumption. Working as a housewife provided time for others to pay attention to nutritional intake for themselves and their families.

This study found that there is a relationship between iron protein intake and $\mathrm{Hb}$ levels $(p=0.000)$. Other studies also have shown a significant relationship between iron intake and hemoglobin levels. ${ }^{15,16}$ Iron has a vital role in the formation of hemoglobin. The higher iron intake, the better hemoglobin levels. ${ }^{14}$

This study has some limitations. Many things cause anemia in toddlers under-five. This study only limits the problem to the relationship between nutrition intake and hemoglobin levels in toddlers aged 12-24 months. It could have been followed up longer by food or diet intervention to explore the effect of nutritional intake on $\mathrm{Hb}$ levels.

In conclusion, the intake of nutrients consisting of iron has a significant relationship to Hb levels in toddlers aged 12-24 months at the Public Health Center in South Sumedang. An iron-rich nutrition program needs to be well set up for toddlers in this area.

\section{References}

1. Adriani M, Wirjatmadi B. Gizi dan kesehatan balita: peranan mikro zinc pada pertumbuhan balita. Jakarta: Kencana PrenadaMedia Group; 2014.

2. Masthalina H. Pola konsumsi (faktor inhibitor dan enhancer $\mathrm{Fe}$ ) terhadap status anemia remaja putri. KEMAS. 2015;11(1):80-6.

3. Wardhani JP, Rahfiludin MZ, Pradigdo SF. Perbedaan aktivitas fisik, kadar $\mathrm{Hb}$, dan kesegaran jasmani (Studi pada siswi KEK dan tidak KEK di SMAN 1 Grogol Kabupaten Kediri). JKM. 2017;3(3):205-12.

4. Badan Penelitian dan Pengembangan Kesehatan Kementerian Kesehatan RI. Riset Kesehatan Dasar (Riskesdas). Jakarta: Badan Penelitian dan Pengembangan Kesehatan Kementerian Kesehatan RI; 2018.

5. Singh, Patra. Extent of anaemia among preschool children in EAG States, India: A challenge to policy makers. Anemia. 2014;2014:868752.

6. Fitriany J, Saputri AI. Anemia defisiensi besi. Averrous. 2018;4(2):1-14.

7. VanBuskirk KM, Ofosu A, Kennedy A, Denno DM. Pediatric anemia in rural Ghana: a cross-sectional study of prevalence and risk factors. J Trop Pediatr. 2014;60(4):308-17.

8. Ekorinawati W. Hubungan asupan zat besi dengan kadar hemoglobin dan kadar ferritin pada anak usia 6 sampai 24 Bulan di Puskesmas Kratonan [minor thesis]. Surakarta: Universitas Muhammadiyah Surakarta; 2010.

9. Kementrian Kesehatan RI.. Profil kesehatan Indonesia tahun 2016. Jakarta: Kemenkes RI; 2017

10. Nurhidayati A, Hapsari E. Hubungan asupan nutrisi dengan kadar $\mathrm{Hb}$ Pada ibu hamil di BPS Suratini Suwarno Surakarta. Jurnal Kesehatan Kusuma Husada. 2014; $5(1): 47$

11. Mustofa FL, Rusmini H. Hubungan kebiasaan sarapan pagi dan kadar hemoglobin terhadap konsentrasi belajar pada mahasiswi Program Studi Kedokteran angkatan 2014 Universitas Malahayati Bandar Lampung. Jurnal Medika Malahayati. 2014;1(3):113-8. 
12. Putri RF, Sulastri D, Lestari Y. Faktor-faktor yang berhubungan dengan status gizi anak balita di wilayah kerja Puskesmas Nanggalo Padang. Jurnal Kesehatan Andalas. 2015;4(1):254-61

13. Rahmawati S. Hubungan tingkat pendidikan dan status pekerjaan ibu dengan pengetahuan ibu tentang anemia pada anak balita di Kelurahan Nambangan Kidul Kecamatan Manguharjo Kota Madiun [minor thesis]. Surakarta: Universitas Muhammadiyah Surakarta; 2015.

14. Silvia A, Kartini A, Nugraheni SA. Hubungan asupan zat gizi (protein, zat besi, vitamin c) dan pola (Siklus, lama) menstruasi dengan kadar hemoglobin (Studi pada Remaja Putri di SMK Negeri 10 Semarang). JKM: Jurnal Kesehatan Masyarakat (e-Journal). 2019;7(4):504-16.

15. Pradanti CM, Wulandari M, K Sulistya H. Hubungan asupan zat besi ( Fe) dan vitamin c dengan kadar hemoglobin pada siswi kelas VIII SMP Negeri 3 Brebes. Jurnal Gizi UNIMUS. 2015;4(1):24-9

16. Al Rahmad AH. Pengaruh asupan protein dan zat besi (Fe) terhadap kadar hemoglobin pada wanita bekerja. Jurnal Kesehatan. 2017;8(3):321-5. 